\title{
Job Satisfaction: Mediating Variable of Vocational High School Teacher's Performance
}

\author{
T Murwaningsih ${ }^{1}$, Wahjoedi ${ }^{2}$, H Wahyono ${ }^{3}$, and B E Soetjipto ${ }^{4}$ \\ $\left\{{ }^{1}\right.$ murwaningsih_tri@staff.uns.ac.id, ${ }^{2}$ wahjoedi@um.ac.id, ${ }^{3}$ ayong@ekofeum.or.id, \\ ${ }^{4}$ soetjiptobe@yahoo.com\} \\ ${ }^{1}$ Universitas Sebelas Maret, Surakarta, Indonesia \\ ${ }^{2,3,4}$ Universitas Malang, Malang, Indonesia
}

\begin{abstract}
This study aims to investigate the effect of teacher's professionalism, teacher's welfare, teacher's sustainable self-development, and job satisfaction to the performance of the teacher. The study used quantitative approach using correlational descriptive. The total of 155 teachers has participated. Stratified proportional sampling was used in this study. The data were collected using questionnaire and analyzed using structural equation modeling (SEM). The results of the study are: 1). Teacher professionalism has a significant effect on teacher welfare but it has not a significant effect on teacher sustainable selfdevelopment, job satisfaction, and teacher performance. Teacher professionalism has an indirect effect on teacher sustainable self-development and job satisfaction using teacher welfare as mediation variable; 2). Teacher welfare has a significant effect on teacher sustainable self-development and job satisfaction but it has not a significant effect on teacher performance. Teacher welfare has an indirect effect on teacher performance using teacher sustainable selfdevelopment as a mediating variable; 3 ). Teacher sustainable self-development has a significant effect on teacher performance, but it has not a significant effect on job satisfaction; and 4). Job satisfaction has not a significant effect on teacher performance.
\end{abstract}

Keywords: job satisfaction, teacher's performance, self-development

\section{INTRODUCTION}

In the globalization era, all sectors of education are required to have a high quality of education system. [1] state "globalization refers to the two rapid and massive movement of capital, goods, people, ideas, institutions and images across the globe". Teachers are an important part of education. In Indonesia, there are so many challenges have to be faced by the teachers. [2] states "teacher is required to be competence in practice having mastered a body of knowledge". The role of the teacher can be improved through a certification program that judging a professional teacher to do teaching and to increase the teaching and learning process. The performance of certified teacher needs to be evaluated continually in certain period. [3] states "although there is much evidence to support the cause and effect of the study (a correlative study does not support the finding) the satisfaction has more affecting the performance better than performance affecting the satisfaction". The factors affecting satisfaction are sustainable professional self-development, professional reward, and professionalism. The activity of teacher 
sustainable self-development cannot be separated from financial support that relates to teacher welfare. A teacher, as a professional job, refers to the teacher income consisting of earn, professional reward, and other reward relate to the job.

Teacher's performance including its factors needs to be continuously explored. The requirement of improvement of vocational high school teacher performance creates a dilemma. The program of certifying teacher requires sustainable self-development but there are many regulations that fetter the teacher. For instance, the regulation of teacher's workload is 24 to 40 hours per week, the government's policy for state school to open parallel class until 8 rooms. It is impossible for teacher doing two activities at the same time: doing sustainable selfdevelopment and teaching eat least 24 hours. On the other side, teacher welfare is an important factor for teacher's performance. Although teachers have received incentive but they were not called welfare teachers (still processing to be welfare teachers)

\section{RESEARCH METHOD}

\subsection{Teacher performance}

Performance appraisal is a formal management system that provides for the evaluation of the quality of an individual's performance in an organization [4]. Performance appraisal is a process; it is not a final form. Its structures your relationship with employees while providing legal protection for your company [5]. [6] states "the appraisal of teacher performance is an evaluation of each item of teacher's main task in the context of career development on its rank and position". [7] states "personal appraisal is affected by the culture and structure of an organization, work design, reward system which was used to motivate and empower of employee and political organization and group". [4] explains five elements should appear in every performance appraisal form: (1) organizational core competencies, (2) job family competencies, (3) key job responsibilities, (4) projects and goals, and (5) major achievements. [5] states "...performance appraisals can (1) motivate employees to perform better and produce more, (2) help you identify development and training needs, (3) help employees understand how they can develop and grow, (4) increase employee morale, (5) improve the respect employees have for their managers and senior management, (6) faster good communication between your staff and you, (7) identify poor performers and help them get on track, and (8) lay the groundwork to fire poor performers lawfully and fairly if they don't improve. [8] explains six criteria of work appraisal form "quality, (2) quantity, (3) timelines, (4) cost-effectiveness, (5) need for supervision, and (6) interpersonal impact". The aspects of work appraisal above are mentioned on the [6] that explaining "teacher is a professional educator who has main task educating, teaching, guiding, directing, training, assessing and evaluating students of children education in the formal education, primary and secondary education". [9] states "among the eight standards (including 42 criteria), the following six frameworks are competence in content knowledge, competence in planning and preparing for instruction, methods for instruction and assessment of student learning, competence in classroom management, engagement in professional growth and fulfilment of professional responsibilities". [9] mentions four criteria of work appraisal, namely, (1) planning and preparation, (2) the classroom environment, (3) instruction, and (4) professional responsibilities. [10] explains four indicators of teacher's performance appraisal are (1) pedagogical, (2) personality, (3) professional, and (4) social competence. 


\subsection{Job satisfaction}

[11] argues "job satisfaction is a positive feeling about a personal job which is the result of characteristic evaluation". [3] states "job satisfaction is the result of employee's perception about how well the work gives things that considered important". Job satisfaction is related to personal emotion and feeling in response an activity. It means that job satisfaction is the result of employee perception on the situation and condition work environment based on the evaluation of its characteristics. Many factors influence personal job satisfaction. Job descriptive index (JDI) explains "the factors influencing job satisfaction are (a) work at the right place, (b) appropriate earn, (c) organization and management, (d) supervision on the right job, and (e) the right man on the right job". The data of job satisfaction can refer to the instrument of JDI. [12] explains "job satisfaction evaluation can be indicated from (1) satisfaction with supervisor, (2) satisfaction with job, (3) satisfaction with company policy, (4) satisfaction with promotion, (5) satisfaction with pay, (6) satisfaction with co-workers, (7) satisfaction with customers". [13] explains "Each-item measured a dimension of the satisfaction construct degree of satisfaction with the work, co-workers, supervision, total pay, and promotional opportunities".

\subsection{Sustainable Self-development}

[14] states "a professional who has both grown in personal conscience and internalized the other four elements of professionalism would have high degrees of professional ethical sensitivity, professional moral reasoning, ethical professional identity, and professional moral implementation. According to [15] the aspects of education for sustainable self-development (1) is based on the principles and values that underlie SD, (2) deals with the wellbeing of all three realms of sustainability - environment, society and economy, (3) Promotes life-long learning, (4) is locally relevant and culturally appropriate, (5) is based on local needs, perceptions and conditions, but acknowledges that fulfilling local needs often has international effects and consequences, (6) engages formal, non-formal and informal education, (7) accommodates the evolving nature of the concept of sustainability, (8) addresses content, taking into account context, global issues, and local priorities; Builds civil capacity for communitybased decision-making, social tolerance, environmental stewardship, adaptable workforce and quality of life, (9) is interdisciplinary. No one discipline can claim ESD for its own, but all disciplines can contribute to ESD; and (10) uses a variety of pedagogical techniques that promote participatory learning.

\subsection{Teacher welfare}

[16] states "economy could increase the welfare". [17] argues "the implementation of welfare reforms is ongoing; suitable stable accommodation has been identified as an element effective resettlement". The welfare concept according to [18] about social welfare is a condition with fulfilling of materials need, spiritual, and social of resident to get an appropriate survive and an effort to develop themselves in order to do the social function. In details, [19] explains "everyone works in expectation of some reward, and welfare is one of them...employees with different education levels and positions perceive different employee benefit impacts; employee benefit programmes have a greater influence on younger employees' performance". [20] explains "welfare is a prosperous condition that generally covers physical, spiritual, and social and it covers more than the improvement and eradication of social ills". The definition of prosperous family according to [21] is the family that can fulfil the need of 
families' member including clothing, food, housing, social and religion, families that have a balance between family income and the number of family members, families who can meet the health needs of family members, life together with the surrounding community, devoted worship besides fulfilling basic needs. [16] explains the welfare is "(1) standard of living cost, (2) healthy, (3) education, (4) personal activity, (5) political voice and governance, (6) relations and social kinship, (7) environment (present and future conditions), and (8) insecurity, both economic and physical". Welfare often relates to pay satisfaction and measured using pay satisfaction questionnaire (pSQ). For instance, [22] states "developed the pSQ to reflect this multidimensionality. The pSQ subsequently has become a popular instrument because it can be used to better understand satisfaction with the various components of compensation (e.g. based pay, raises, benefits, structure/administration)". pSQ comprises 18 items breakdown from four dimensions of satisfaction, namely, income level, increase income, incentive, and structure/administration. Income level consists of current income, total income, and the amount of current income and the earn bring to the home. Incentive covers incentive platform, amount of incentive paid, amount of incentive, and the total of incentive. Increasing earn consists of supervisor effect on the earn, the way to decide the earn increases, the last increasing earn and the previous increasing earn. Administration and structure involve the administration of paying earn, the mount earns for other job positions in the company, consistent earn policy, earning structure, information and earn differences. The indicators of welfare families according to [23] are (1) basic needs, (2) psychological needs, (3) developmental needs.

\subsection{Teacher professionalism}

Teacher professionalism is related to the teaching profession. [24] argues teacher professionalism is the attitude of a professional who keep his professional ability. [25] enlighten the characteristics of professional are (1) subject knowledge, (2) teaching prowess, (3) updating knowledge, (4) collegiality, (5) commitment, (6) teacher-student relationship, (7) empowerment, 8) self-development, (9) remuneration, and (10) ethical code of conduct. [14] describes four professional aspects (1) professional ethical sensitivity, (2) professional moral reasoning, (3) ethical professional identity, and (4) professional moral implementation. [26] states the professionalism covers (1) a common body of knowledge resting on a well-developed, widely accepted theoretical base, (2) a system for certifying that individuals possess such knowledge before being licensed or otherwise allowed to practice, (3) a commitment to use specialized knowledge for the public good, a renunciation of the goal of personal profit maximization in return for professional autonomy and monopoly power, (4) a code of ethics, with provisions for monitoring compliance with the code and a system of sanctions for enforcing it".

This study uses descriptive quantitative approach. The population of this study is the vocational high school teacher in Soloraya. Soloraya comprises of six regencies covering Karanganyar, Sragen, Boyolali, Sukoharjo, Wonogiri, and Klaten, and one municipality of Surakarta. The total of vocational high school in Soloraya is 21 schools with 222 certified teachers. Proportional random sampling was used to collect the data with 155 teachers were participated coming from 16 schools. The data were analyzed using structural equation modeling (SEM). 


\section{RESULTS AND DISCUSSION}

155 teachers were participated in this study. In the beginning, the data were analyzed using critical ration skewness and linearity test using Mahalanobis distance to make sure that the data are normally and linearly distributed. The score of skewness is 1.643 and the kurtosis is .096 ( $p$ $>.05)$. It means that the data are normally distributed population. The score of Mahalanobis distance shows $47.74(p>.05)$ that has a meaning the data are linear. It means that SEM can be conducted.

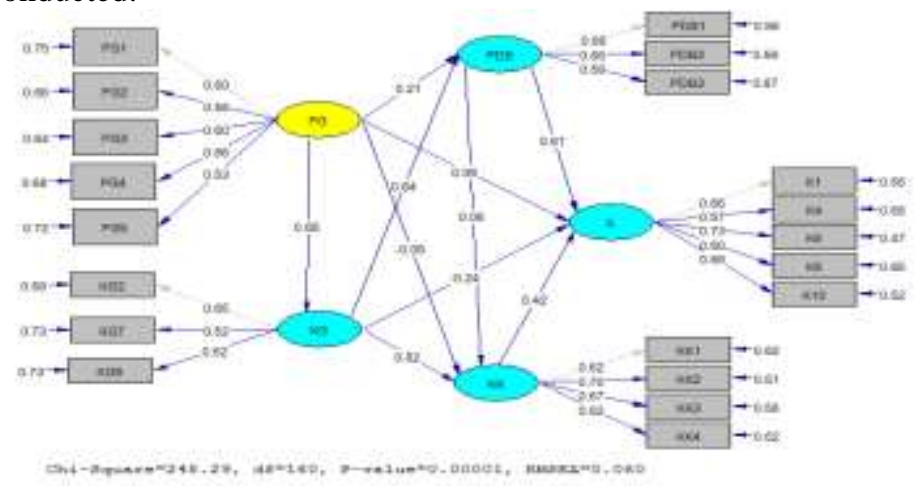

Figure 1. Study design

Table 1. The equity study model

\begin{tabular}{|c|c|c|c|}
\hline Criteria & Cut off & Result & Meaning \\
\hline \multicolumn{4}{|l|}{ Absolute fit } \\
\hline$\chi^{2}$ & (Expected) low score & 248,29 & Intermediate \\
\hline Significancy & $\geq 0.05$ & 0.00001 & \\
\hline$\chi^{2} / \mathrm{DF}$ & $\leq 2.00$ & 1,552 & Good \\
\hline RMSEA & $\leq 0.08$ & 0,060 & Good \\
\hline AGFI & $\geq 0,90$ & 0,91 & Good \\
\hline GFI & $\geq 0.90$ & 0.94 & Good \\
\hline \multicolumn{4}{|c|}{ Incremental fit } \\
\hline CFI & $\geq 0.95$ & 0.95 & Good \\
\hline NFI & $\geq 0.90$ & 0.78 & Intermediate \\
\hline \multicolumn{4}{|c|}{ Parsimony fit } \\
\hline PGFI & $0.6-0.90$ & 0.65 & Good \\
\hline PNFI & Almost perfect 1 & 0.76 & Intermediate \\
\hline
\end{tabular}

Source: Primer Data, 2013

Table 1 shows the $\chi 2$ score is low, the $\chi 2 /$ DF, SMSEA, PGFI is good, and the good of fit score is good. 
Table 2. The result of hipotesis test

\begin{tabular}{|c|c|c|c|c|c|}
\hline \multirow[t]{2}{*}{ Path } & \multicolumn{2}{|r|}{ Effects } & \multirow[t]{2}{*}{ Total } & \multirow[t]{2}{*}{$\mathrm{CR}$} & \multirow[t]{2}{*}{ Meaning } \\
\hline & Direct & Indirect & & & \\
\hline $\mathrm{PG} \rightarrow \mathrm{KG}$ & 0.66 & - & 0.66 & 5,27 & H1 accepted \\
\hline $\mathrm{PG} \rightarrow \mathrm{PDB}$ & 0.21 & - & 0.21 & 1,14 & $\mathrm{H} 2$ rejected \\
\hline $\mathrm{PG} \rightarrow \mathrm{KK}$ & -0.05 & - & -0.05 & 0,29 & H3 rejected \\
\hline $\mathrm{PG} \rightarrow \mathrm{K}$ & 0.09 & - & 0.09 & 0.55 & $\mathrm{H} 4$ rejected \\
\hline $\mathrm{KG} \rightarrow \mathrm{PDB}$ & 0.64 & - & 0.64 & 2,94 & H5 accepted \\
\hline $\mathrm{KG} \rightarrow \mathrm{KK}$ & 0.82 & - & 0.82 & 2.36 & H6 accepted \\
\hline $\mathrm{KG} \rightarrow \mathrm{K}$ & -0.24 & - & -0.24 & 0.59 & H7 rejected \\
\hline $\mathrm{PDB} \rightarrow \mathrm{KK}$ & 0.06 & - & 0.06 & 0,21 & H8 rejected \\
\hline $\mathrm{PDB} \rightarrow \mathrm{K}$ & 0.61 & - & 0.61 & 2.40 & H9 accepted \\
\hline $\mathrm{KK} \rightarrow \mathrm{KG}$ & 0.42 & - & 0.42 & 1,53 & H10 rejected \\
\hline $\mathrm{PG} \rightarrow \mathrm{KG} \rightarrow \mathrm{KK}$ & 0.05 & $(0.66 * 0.82)=0.54$ & 0.59 & & Mediating \\
\hline $\mathrm{PG} \rightarrow \mathrm{KG} \rightarrow \mathrm{PDB}$ & 0.21 & $(0.66 * 0.64)=0.42$ & 0.63 & & Mediating \\
\hline $\mathrm{KG} \rightarrow \mathrm{PDB} \rightarrow \mathrm{KG}$ & 0.24 & $(0.64 * 0.61)=0.39$ & 0.63 & & Mediating \\
\hline
\end{tabular}

Source: Primer Data, 2013

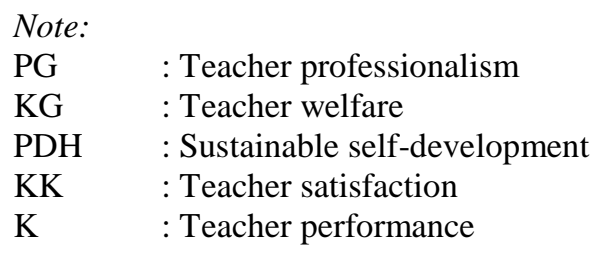

Teacher professionalism has a significant effect on teacher welfare but it has not a significant effect on sustainable self-development, job satisfaction, and teacher performance. Teacher professionalism is indicated by the total of a certified teacher. The effect of the certified program is the teachers receiving the professional incentive that affects the teachers' welfare. Teacher's professionalism has not a significant effect on sustainable self-development. It means the high professionalism of teacher will not affect the sustainable self-development. The high burden teacher, the strict school regulation, funding, and old-age make the teachers have no time to improve themselves. The professionalism of teacher has not a significant effect on teacher satisfaction. It means the high professionalism of teacher does not assure the teacher satisfaction. The teacher feels the overload work, unsuitable teaching materials, and unsupported knowledge to teaching make feel unhappy on the job. Teacher professionalism has not a significant effect on teacher performance. It means the certified teacher cannot assure to be a good teacher. Many teachers have not a good performance on their job because they feel safe after got the professional certificate and they don't want hard work.

Teacher performance has a significant effect on sustainable self-development. If the teacher has fulfilled the need, he/she will spend to sustainable self-development. The high financial support motivates the teacher to join the scientific meeting or buy learning tools to support the teaching process. Teacher welfare has a significant effect on teacher satisfaction. It means the welfare makes the teacher feel peaceful, safe, and comfortable to work.

The teacher welfare has not a significant effect on teacher performance. Although teacher welfare increase it doesn't affect the teacher performance. It happens because of some reasons. 
First, incentive teacher makes him/her busy to spend the money to fulfill the need. He/she has not time to think to be a professional teacher. Second, the high level of teacher welfare is related to the consumptive behavior. The incentive earn does not use to improve the teaching process but to change the lifestyle. On the other side, teacher welfare has an indirect effect on teacher performance which mediated by sustainable self-development. Based on this finding, it can be summarized that teacher welfare can improve teacher performance through sustainable selfdevelopment. A teacher has high welfare and he/she can join the self-development program because of good financial support. Following seminar, short course, and other scientific meeting, teachers can improve teacher's skills. This finding echoes [27] that (1) sustainable selfdevelopment has a significant effect on job satisfaction and teacher performance. In this study, sustainable self-development has not a significant effect on teacher satisfaction. Teacher has not a satisfy with the sustainable self-development. First, teachers do not have time to selfdevelopment. The high burden makes them never think to develop themselves. Second, the regulation about self-development is strict. Many regulations do not support the selfdevelopment, e.g. teacher who wants to come a short course has to have a permission letter from the regional office. Sustainable self-development has a significant effect on teacher performance. The teacher self-development has an effect on her/his performance of teaching and learning. The sustainable self-development has a significant effect on mastering materials, teaching skills, using learning multimedia etcetera. The increasing skills will affect the increasing teacher performance, (2) job satisfaction has not a significant effect on teacher performance. Job satisfaction has not an effect on teacher performance. A teacher has a high satisfaction doesn't mean a high performance of work. The reasons for low performance are: first, the incentive of professionalism is not expedited distributed. The teacher feels satisfied with the incentive earn but because of late coming, it makes him/her lazy to work. It will be better if the incentive earn is given together with the regular earn every month. Second, high teacher dedication. The teacher job relates to the dedication. Teachers don't want to get the financial support but get a reward of worship. They are happy if they can teach students well. This finding supports [28].

\section{CONCLUSIONS}

The result of the study can be concluded as follows:

\subsection{Teacher professionalism has a significant effect on teacher welfare.}

A high professional teacher means high welfare teacher. The teacher professionalism has not a significant effect on sustainable self-development. A high of teacher professionalism means a low teacher satisfaction but teacher professionalism has an indirect effect on teacher satisfaction through teacher welfare as a mediating variable. Teacher professionalism has not a significant effect on teacher performance. It means the high teacher professionalism doesn't affect the teacher performance.

\subsection{Teacher welfare has a significant effect on sustainable self-development.}

High teacher welfare means a high motivation for sustainable self-development. Teacher welfare has a significant effect on teacher satisfaction. High teacher welfare will be followed by high job satisfaction. Teacher welfare has not a significant effect on teacher performance. High welfare will not be followed by the high teacher performance although the teacher welfare has an indirect effect on teacher performance through job satisfaction as a mediating variable. 


\subsection{Sustainable self-development has not a significant effect on teacher satisfaction.}

A high sustainable self-development does not affect the high job satisfaction of teacher. Sustainable self-development has a significant effect on teacher performance. A high sustainable self-development will affect the high of teacher performance.

\subsection{Job satisfaction has not a significant effect on teacher performance.}

High job satisfaction doesn't support the teacher performance.

\section{REFERENCES}

[1] Adam D and Golbard A 2002 Community, Culture and Globalization (New York: The Rockefeller Foundation)

[2] Rhodes C, Stokes M and Hampton G 2004 A Practical Guide to Mentoring, Coaching, and Peer-networking: Teacher Professional Development in Schools and Colleges (London: Routledge Falmer)

[3] Luthans F 2006 Perilaku Organisasi. Edisi Sepuluh (Yogyakarta: Andi)

[4] Grote D 2002 The Performance Appraisal. Question and Answer Book: Survival Guide for Managers. (NewYork: Amacom)

[5] Delpo A 2007 The Performance Appraisal. Hand Book Legal \& Practical Rules for Managers (USA: Consolidated printers)

[6] The Regulation of Minister of State Apparatus Utilization of Bureaucratic Reform of Indonesia No. 162009

[7] Sahinidis A G and Bouris J 2008 Employee Perceived Training Effectiveness Relationship To Employee Attitudes. Journal of European Industrial Training 321 pp 63-76

[8] Kosasih N and Budiani S 2007 Pengaruh Knowledge Management Terhadap Kinerja Karyawan: Studi Kasus Departemen Front Office Surabaya Plaza Hotel. Jurnal Manajemen Perhotelan 32

[9] Isore M 2009 Teacher Evaluation: Current Practices in OECD Countries and Literature Review. OECD Education Working Papers No. 23 (Paris: OECD Publishing)

[10] Peraturan Pemerintah Republik Indonesia Nomor 19 tahun 2005 Tentang Standar Nasional Pendidikan

[11] Robbins and Judge 2007 Perilaku Organisasi . Buku 1 edisi 12 (Jakarta: Salemba Empat)

[12] Boles J, Madupalli R, Rutherford B and Wood J A 2007 The Relationship of Facets of Salesperson Job Satisfaction with Affective Organizational Commitment. Journal of Business \& Industrial Marketing 225 pp 311-321

[13] Lund D B 2003 Organizational Culture and Job Satisfaction. Journal of Business \& Industrial Marketing 183 219-236

[14] Hamilton N 2008 Assessing Professionalism: Measuring Progress in the Formation of an Ethical Professional Identity (Minnesota:University of St.Thomas School of Law. Legal Studies Research Paper No. 08-10)

[15] United nation educational, scientific and cultural organization (UNESCO)

[16] Stiglitz et al 2011 Mengukur Kesejahteraan (Jakarta: Wahana Aksi Kritika)

[17] Linney J 2013 Offenders, Welfare Reforms and Housing. Safer Communities 121 pp 2426

[18] Undang-Undang Republik Indonesia Nomor 11 tahun 2009 Tentang Kesejahteraan Sosial 
Chao Hong $\mathrm{J}$ et all 1995 Impact of Employee Benefit on Work Motivation and Productivity International. Journal of Career management 7 10-14

[18] Midgley J 2005 Pembangunan Social: Perspektif Pembangunan dalam Kesejahteraan Sosial (Jakarta : Diperta Islam Depag RI 2005)

[19] Badan Kependudukan dan Keluarga Berencana Nasional 2005

[20] Judge T and Welbourne T M 1993 Dimensionality of the Pay Satisfaction Questionnaire: A Confirmatory Factor Analytic Investigation. CAHRS Working Paper \#93-09 (Ithaca, NY: Cornell University, School of Industrial and Labor Relations, Center for Advanced Human Resource Studies)

[21] Badan Kependudukan dan Keluarga Berencana Nasional 2011

[22] Saudagar A and Idrus A 2009 Pengembangan Profesioalisme Guru (Jakarta: Gaung Persada)

[23] Krishnaveni R and Anitha J 2007 Educators' professional Characteristics. Quality Assurance in Education 152 pp 149-161

[24] Cabrera A and Bowen D 2005 Professionalizing global management for the twenty-first century. Journal of Management Development 249 pp 791-806

[25] Jones J J and Walters D L 2008 Manajemen sumber daya manusia dalam pendidikan (Yogyakarta:Q-Media)

[26] Yohana C 2012 Pengaruh Profesionalisme, Kepuasan Kerja dan Komitmen Organisasi Terhadap Kinerja Guru di SMPN Pamulang-Tangerang Selatan. Jurnal Ilmiah Econo Sains 102 pp 131-143 